\title{
Subject Delay in Providing Consent
}

National Cancer Institute

\section{Source}

National Cancer Institute. Subject Delay in Providing Consent. NCI Thesaurus. Code

C100016.

The subject has not provided consent in a timely manner for the procedure to take place.

(ACC) 